УДК 658. 33

JEL Classification; F21; F36; F63

http://doi.org/

О.О. Кулаков

\title{
РЕАЛІЗАЦІЯ РЕФОРМИ ДЕРЖАВНОЇ СЛУЖБИ ЩОДО БІЛЬШОЇ УЧАСТІ ГРОМАДЯН В ІНВЕСТИЦЙННИ ПРОЦЕСАХ ДЛЯ ЄВРОПЕЙСЬКОЇ ТА СВРОАТЛАНТИЧНОЇ ІНТЕГРАЦІЇ УКРАЇНИ
}

\begin{abstract}
Мета. Аналіз реалізачї̈ реформи державної служби щэодо більшої участі громадян в інвестищійних процесах для європейської та євроатлантичної інтеграиії України.

Методика. Досліджено різні форм участі громадян у процесах державного управління, щзо дозволяє сформувати гарний баланс переваг і недоліків в иььому прочесі для впровадження євроінтеграційних реформ на основі методів теоретичного узагальнення, групування та порівняння. Аналіз основних переваг і недоліків сприяння участі громадян у прочесах державного управління базується на методології системного аналізу і синтезу.

Результати. Виявлено на основі аналізу основних переваг і недоліків, що переваг від участі громадян у процесах державного управління значно більше ніж недоліків для забезпечення кращьої якості послуг та рівня життя громадян. Досліджено головні недоліки участі громадян у прочесах державного управління, щяо допоможе вирішувати проблеми участі громадян у процесах державного управління в контексті євроінтеграції. Розроблені різні форми участі громадян у процесах державного управління для того, шеб сформувати гарний баланс переваг $і$ недоліків в иьому прочесі з метою впровадження євроінтеграційних реформ. Проаналізовано створені різні рівні участі громадян у процесах державного управління, щзо сприяє ефективному залученню громадян до прочесів державного управління для реалізачії євроінтеграчійних реформ. Виявлено, що підтримка процесів соиіально-економічної реформи державної служби через стратегію державного управління допоможе здійснити основні європейські адміністративні реформи державного управління в Украӥні. На основі аналізу зроблено висновок, що підтримка трансформаційних процесів в Украӥні иляхом інвестування в реформування державноі служби допомагає побудувати основні європейські принциипи держсавного управління в Україні. Обтрунтовано, щзо заходи з підтримки громадянського суспільства стануть можливими завдяки професійній підготовиі державних службовців, щฺо дасть можливість побудувати стабільну та ефективну економіку України.

Наукова новизна. Обтрунтовано доцільність створення різних рівнів участі громадян у процесах державного управління: інформування, консультування, рекомендащії, спільне вироблення планів, спільні рімення, делегування.

Практична значимість. Результати дослідження формують науково-практичне підгрунтя для проведення варіативних аналітико-прогнозних досліджень в частині обтрунтування більшої участі громадян в інвестиційних процесах держсавного управління.
\end{abstract}

Ключові слова: інвестування, інвестииійний прочес, європейська та євроатлантична інтеграція, процеси державного управління, реформа державної служби, професійна підготовка державних службовиів, участь громадян

Вступ. На сучасному етапі розвитку вітчизняної економіки виникає проблема реформи державної служби в контексті більшої участі громадян у процесах державного управління як шляху до євроінтеграції. В економіку України надходять багато іноземних інвестицій з різних країн Європейського Союзу (далі - СС), тому громадяни прагнуть бачити прозоре використання інвестиційних надходжень. Іноземні інвестиції допомагають розвивати економіку України, а саме розвивають державне управління, покращують економічний розвиток, удосконалюють гуманітарну ситуацію, модернізують необхідну інфраструктуру, надають підтримку малому та середньому бізнесу тощо. Виникає необхідність зробити необхідні зміни в державному управлінні, щоб міжнародні інвестиції використовувалися 3 принципами підзвітності та сприяли розвитку економіки країни. Також збільшення міжнародних інвестицій потрібно для наукового розвитку економіки України, оскільки науковий напрям розвитку економіки $є$ провідним для найрозвиненіших країн ЄС. Зростання вимог до компетентності державних службовців через європейську інтеграцію України вимагає вивчення зарубіжного досвіду державного управління. Для впровадження успішного досвіду державного управління європейських країн необхідна професійна підготовка державних службовців. Отже, реформа державного управління в контексті європейської інтеграції України $\epsilon$ актуальною.

Аналіз останніх досліджень i публікацій. Актуальним питанням та проблемам розвитку інвестування присвячено ряд публікацій вітчизняних вчених-економістів. В працях Ю. Ратушної досліджуються фактори розвитку іноземного фінансового інвестування $[1$, с. 60]. Іноземні інвестиції в сільському господарстві України: сучасний стан та вплив на його розвиток розглядаються $\mathrm{y}$ працях Н. Патики [2, с. 27]. В наукових працях А. Маренич приділяється увага інвестиційній 
політиці у стратегії розвитку регіону [3, с. 144]. В. Покиньчередою досліджуються інвестиції в людський капітал: проблеми облікового відображення [4, с. 48]. Л. Козак розглядаються іноземні інвестиції в економіці України [5, c. 110]. О. Тимошенко аналізуються особливості та перспективи залучення іноземних інвестицій в Україну в контексті забезпечення економічної безпеки національної економіки [6, с. 88]. В дослідженнях $€$. Редзюк приділяється увага прямим іноземним інвестиціям: можливості для продуктивного економічного зростання в Україні [7, с. 97]. О. Бервено досліджується стимулювання інвестиційної діяльності торговельних підприємств [8, с. 173].

Відзначаючи вагомий внесок вітчизняних вчених-економістів у розвинення питань теорії та практики розвитку інвестування слід зауважити, що недостатньо досліджено реалізація реформи державної служби щодо більшої участі громадян в інвестиційних процесах для європейської та євроатлантичної інтеграції України.

Мета статті (постановка завдання). Метою статті $\epsilon$ аналіз реалізації реформи державної служби щодо більшої участі громадян в інвестиційних процесах для європейської та євроатлантичної інтеграції України.

Теоретичною та методологічною основою дослідження $є$ практичні та фундаментальні наукові дослідження економічної науки, наукові праці закордонних i вітчизняних фахівців. Досягнення зазначеної мети забезпечено використанням дослідження різних форм участі громадян у процесах державного управління, що дозволяє сформувати гарний баланс переваг і недоліків в цьому процесі для впровадження євроінтеграційних реформ на основі методів теоретичного узагальнення, групування та порівняння. Аналіз основних переваг і недоліків сприяння участі громадян у процесах державного управління базується на методології системного аналізу і синтезу.

Виклад основного матеріалу. Наведемо основні переваги сприяння участі громадян у процесах державного управління:

1. Участь громадян веде до поліпшення рівності доступу до розроблення державних рішень. Коли державні органи організовують процеси участі громадян, все більше людей будуть почутими, що повинно призвести до покращення державного управління та послуг, які матимуть більшу користь для всіх людей.
2. Участ
громадян
призводить
до

поліпшення якості прийняття державних рішень. Організовуючи процеси участі, державні службовці краще усвідомлюють потреби людей. Це дозволяє краще вирішити актуальні проблеми та дозволяє уникнути опору громадян при впровадженні державних рішень 3 управління. Громадяни можуть також мати цінні навички або знання, які сприятимуть підвищенню якості державних рішень 3 управління.

3. Державні органи підвищують легітимність уряду та довіру громадян до влади. Процеси справжньої участі доводять, що державні органи працюють задля громадян та суспільного блага, а потреби громадян $\epsilon$ головними у державних рішеннях. Це сприяє розвитку економіки та зменшує опір громадян уряду.

4. Коли уряди підтримують участь громадян, вони сприяють активному життєвій позиції громадян. Коли люди можуть впливати на державні органи, вони прийматимуть більш активну роль у розвитку економіки. Це, в свою чергу, може призвести до посилення соціальної згуртованості та стійкості місцевих громад.

Участь громадян може одночасно мати і свої недоліки:

- може бути відкладено прийняття рішення;

- використання багато ресурсів, таких як час і гроші;

- певна група людей може просувати свої інтереси;

- може виникати конфлікт;

- зменшення ролі представницької демократії;

- часто виникають труднощі, які потрібно подолати, щоб вислухати думки людей.

Державні службовці часто бояться результатів участі громадян тому, що це не відповідає їхньому порядку денному, або просто бояться втратити контроль. Участь громадян займає час і може бути складною, але роль громадян, які приймають рішення, велика у вирішенні проблем шляхом налагодження належних процесів 3 гарним балансом переваг i недоліків. Участь громадян призводить до вищої якості результату державних рішень, а державні службовці краще задовольняють фактичні потреби громадян.

Участь громадян може бути різних форм:

- неструктурована - структурована;

- неформальна - формальна;

- пасивна - активна;

- індивідуальна - колективна;

- неоплачувана - платна; 
- безініціативна - ініціативна;

- корисна - альтруїстська;

- протидіє соціальним змінам - стимулює соціальні зміни.

Участь громадян може бути різних рівнів:

1. Інформування - це одностороннє спілкування державних службовців 3 громадянами, розповідаючи їм про плани, закони, послуги. Громадяни не мають контролю або прямого впливу.

2. Консультування, коли державні службовці будуть запитувати людей про їх думку щодо майбутнього плану або щодо надання послуг. Потім державний службовець враховуватиме цей внесок при складанні плану. Консультаційні процеси дають громадянам можливість бути почутими.

3. Рекомендації, коли державні службовці заохочують людей пропонувати ідеї чи ініціативи, що допоможуть покращити плани або послуги. Державні службовці можуть запрошувати експертів-громадян, технічних експертів або комітети громадян. Цей тип участі передбачає обговорення та обмін думками між державними службовцями та членами громади. Однак державні службовці зберігають за собою право відхиляти пропозиції.

4. Спільне вироблення планів, коли державні службовці та громадяни спільно працюють як партнери для розробки або реалізації плану чи послуги. Результат спільного вироблення планів може бути відхилений державними службовцями, але лише 3 вагомою аргументацією.

5. Спільні рішення - це співпраця, заснована на рівності. Громадяни мають право голосу при прийнятті рішень і рівний голос. Державні службовці повинні прийняти результати процесу спільного прийняття рішень.

6. Делегування, коли громадяни мають свободу самостійно організовувати послуги або розробляти плани. Державні службовці сприяють процесу та встановлюють критерії, але безпосередньо не беруть участі у плануванні та реалізації. Самоорганізація громадян може бути частиною більшої програми, а може бути самостійною програмою сама по собі.

Індивідуальні ресурси, які люди повинні мобілізувати та організувати можуть бути різними в залежності від участі громадян. Щоб взяти участь у державних рішеннях, потрібна ідентифікація 3 державним органом, який $\epsilon$ центром участі. Іншими словами, громадянин повинен мати почуття спільноти та соціального зв'язку 3 місцевістю, в якій він проживає. Державні службовці повинні мати правильне ставлення до громадян, щоб дозволити участь. Необхідна мобілізація людей до участі шляхом прохання про їх внесок. Тому громадян слід явно запросити взяти участь у державних процесах. Державні службовці не повинні погодитися 3 усіма рішеннями громадян, але принаймні державні службовці повинні визнати внесок громадян. Але переваг від участі громадян значно більше ніж недоліків, незважаючи на аргументи проти процесів участі громадян.

Необхідно розробити план дій щодо стратегії реалізації реформи державної служби в Україні.

План дій щодо стратегіï реалізації реформи державної служби в Україні складається з чотирьох напрямків, що включає:

1) Розвиток міжнародного та міжрегіонального співробітництва. 3 метою вивчення досвіду ЄС у всіх аспектах реформи державної служби слід організувати професійну підготовку українських державних службовців. Для поліпшення умов співпраці України 3 іншими країнами в гуманітарній, культурній, освітній, ІТ-галузі тощо необхідно організувати навчання для підвищення кваліфікації державних службовців.

2) Зростання економіки України. Необхідно підтримувати та розвивати малі та середні підприємства як основу економіки України. Важливо збільшити кількість самозайнятих людей для створення нових робочих місць. У довгостроковій перспективі важливо забезпечити пошук неурядових організацій та залучення небюджетних (грантових) коштів для реалізації проєктів, що мають вирішальне значення для ефективного розвитку України.

3) Запобігання зростанню диспропорцій, які уповільнюють розвиток регіонів України. Цей напрямок включає тренінги на тему «ITтехнології» для жителів економічно менш розвинених територій. Реалізація цього проєкту можлива за допомогою проєктів та програм міжнародної технічної допомоги.

4) Посилення територіальної координації при плануванні та реалізації регіональних документів. Система управління розвитком економіки в Україні реформується та будується відповідно до практики ЄС. Регіональні спеціалісти органів виконавчої влади та місцевого самоврядування відчувають брак європейського досвіду, насамперед щодо 
стратегічного планування та управління проєктами регіонального розвитку, цю потребу можна задовільнити за допомогою відповідних курсів навчання (семінарів, тренінгів тощо).

Основною ідеєю інвестування в реформування державної служби є підтримка персоналу державних службовців, які зосереджені на реформах. Для інвестування в реформування державної служби необхідно забезпечити вивчення європейського досвіду у таких сферах: демократія, верховенство права, створення організаційної структури органів державної влади, ефективне управління тощо.

Основними принципами реформування державної служби є:

- вивчення найкращих європейських практик щодо реформ у різних сферах управління;

- діяльність, ініціативи та практичні заходи, засновані на верховенстві права та послідовному впровадженні;

- передача знань у контексті створення та розвитку більш ефективних, прозорих та більш відкритих органів державної влади;

- оцінка державних службовців та державного управління;

- прозорість державної діяльності та державного управління;

- зміцнення та підтримання громадянського суспільства в межах можливостей його діяльності в рамках державної системи;

- підтримка ключових елементів більш активного громадянського суспільства, яке сприймається як сила у майбутньому, що будуть зосереджені на демократії.

Обговорення результатів. Отримані результати наукового дослідження дозволяють стверджувати про доцільність створення різних рівнів участі громадян у процесах державного управління: інформування, консультування, рекомендації, спільне вироблення планів, спільні рішення, делегування. Результати дослідження формують науково-практичне підгрунтя для проведення варіативних аналітико-прогнозних досліджень в частині

\section{Список літератури}

1. Ратушна Ю. Фактори розвитку іноземного фінансового інвестування. Науковий вісник Ужгородського національного університету. Серія : Міжнародні економічні відносини та світове господарство. 2019. № 24 (3). С. 5966.

2. Патика Н. Іноземні інвестиції в сільському господарстві України: сучасний стан та вплив обгрунтування більшої участі громадян в інвестиційних процесах державного управління. Проведене дослідження свідчить про важливість впровадження реформи державної служби в контексті більшої участі громадян у процесах державного управління як шляху до євроінтеграції для розвитку економіки. На основі аналізу основних переваг сприяння участі громадян у процесах державного управління виявлено, що переваг від участі громадян значно більше ніж недоліків для забезпечення кращої якості послуг та рівня життя громадян. Виявлено основні недоліки участі громадян у процесах прийняття державних рішень, що допоможе справлятися 3 проблемами участі громадян у процесах прийняття державних рішень в контексті євроінтеграції. Досліджені різні форми участі громадян у процесах державного управління, що дозволить сформувати гарний баланс переваг i недоліків в цьому процесі для впровадження євроінтеграційних реформ. Проаналізовано різні рівні участі громадян у процесах прийняття державних рішень, що дозволить ефективно залучати громадян до прийняття державних рішень та реалізувати євроінтеграційні реформи.

Висновки. Підтримка процесів соціально-економічної реформи державної служби через стратегію державного управління допоможе здійснити основні європейські адміністративні реформи державного управління в Україні. Виявлено, що підтримка трансформаційних процесів в Україні шляхом інвестування в реформування державної служби допомагає побудувати основні європейські принципи державного управління в Україні. Проаналізовано, що заходи 3 підтримки громадянського суспільства стануть можливими завдяки професійній підготовці державних службовців, що дасть можливість побудувати стабільну та ефективну економіку України.

на його розвиток. Інвестиції: практика та досвід. 2018. № 5. С. 26-31.

3. Маренич А., Пилипенко В. Інвестиційна політика у стратегії розвитку регіону. Фінансовий простір. 2018. № 2 (30). С. 143151.

4. Покиньчереда В. Інвестиції в людський капітал: проблеми облікового відображення. Облік і фінанси. 2018. № 2. С. 47-53.

5. Козак Л., Цвєтков Д. Іноземні інвестиції в 
економіці України. Економіка та управління на транспорті. 2017. № 4. С. 109-115.

6. Тимошенко О., Лісковецька Т. Особливості та перспективи залучення іноземних інвестицій в Україну в контексті забезпечення економічної безпеки національної економіки. Бізнес Інформ. 2017. № 9. С. 87-92.

7. Редзюк Є. Прямі іноземні інвестиції: можливості для продуктивного економічного зростання в Україні. Фінанси Украӥни. 2017. №3. C. 96-110.

8. Бервено О., Мірошниченко Ю. Стимулювання інвестиційної діяльності торговельних підприємств. Проблеми економіки. 2017. № 1. С. 172-177.

\section{References}

1. Ratushna, Yu. (2019). Factors of the development of foreign financial investment. Uzhorod National University Herald. International Economic Relations And World Economy, 24 (3), 59-66 [in Ukrainian].

2. Patyka, N. (2018). Foreign investment in agriculture of Ukraine: current status and impact on its development. Investments: Practice And Experience, 5, 26-31 [in Ukrainian].

3. Marenych, A. \& Pylypenko, V. (2018). Investment policy in the development strategy of the region. Financial space, 143-151 [in Ukrainian].

4. Pokynchereda, V. (2018). Investing in human capital: problems of accounting. Accounting and Finance, 2, 47-53 [in Ukrainian].

5. Kozak, L. \& Tsvietkov, D. (2018). Investment policy in the development strategy of the region. Financial space [in Ukrainian].

6. Tymoshenko, O. \& Liskovetska, T. (2017). Features and prospects of attracting foreign investment in Ukraine in the context of ensuring the economic security of the national economy. Business Inform [in Ukrainian].

7. Redziuk, Ye. (2017). Foreign direct investment: opportunities for productive economic growth in Ukraine. Finance of Ukraine, 3, 96-110 [in Ukrainian].

8. Berveno, O. \& Miroshnychenko, Yu. (2017). Stimulation of investment activity of trade enterprises. The problems of economy, 1, 172-177 [in Ukrainian].

Надійшла до редакиії 12.11.2019p.

Кулаков Олексій Олексійович - доктор філософії з економічних наук (к.е.н.), головний спеціаліст відділу міжнародного та міжрегіонального співробітництва управління зовнішньоекономічних відносин, Департамент інвестиційно-інноваційного розвитку і зовнішніх відносин

Донецької обласної державної адміністрації

E-mail: oleksiikulakov@ukr.net

\title{
IMPLEMENTATION OF CIVIL SERVICE REFORM REGARDING GREATER PARTICIPATION OF CITIZENS IN INVESTMENT PROCESSES FOR EUROPEAN AND EURO-ATLANTIC INTEGRATION
}

\begin{abstract}
The purpose of the article is to analyze the implementation of civil service reform to increase citizen participation in investment processes for European and Euro-Atlantic integration of Ukraine. Methodology. Various forms of citizen participation in public administration processes, which allows to form a good balance of advantages and disadvantages in this process for the implementation of European integration reforms is based on the methods of theoretical generalization, grouping and comparison have been researched. The analysis of the main advantages and disadvantages of promoting citizen participation in public administration processes is based on the methodology of system analysis and synthesis. Results. It was identified on the basis of the analysis of the main advantages and disadvantages that the advantages of citizen participation in public administration processes far outweigh the disadvantages to ensure better quality of services and living standards of citizens. The main shortcomings of citizen participation in public administration processes have been studied, which will help solve the problems of citizen participation in public administration processes in the context of European integration. Various forms of citizen participation in public administration processes have been developed in order to form a good balance of advantages and disadvantages in this process in order to implement European integration reforms. Different levels of citizen participation in public administration processes are analyzed, which contributes to the effective involvement of citizens in public administration processes for the implementation of European integration reforms. It was found that supporting the processes of socio-economic reform of the civil service through the strategy of public administration will help to implement the main European administrative reforms of public administration in Ukraine. Based on the analysis, it is concluded that supporting the transformation processes in Ukraine by investing in civil service reform helps to build the basic European principles of public administration in Ukraine. It is substantiated that measures to support civil society will be
\end{abstract}


possible due to the training of civil servants, which will provide an opportunity to build the stable and efficient economy of Ukraine. Scientific novelty. The expediency of creating different levels of citizen participation in public administration processes is substantiated: informing, consulting, recommendations, joint development of plans, joint decisions, delegation. Practical significance. The results of the study form the scientific and practical basis for conducting various analytical and forecasting studies in terms of justifying greater participation of citizens in investment processes of public administration.

Keywords: investment, investment process, European and Euro-Atlantic integration, public administration processes, civil service reform, professional training of civil servants, citizen participation

Kulakov Oleksii - PhD (economics), chief specialist of branch of international and interregional cooperation of the division of foreign economic relations,

Department of investment innovative development and foreign relations,

Donetsk regional state administration

E-mail: oleksiikulakov@ukr.net

\section{РЕАЛИЗАЦИЯ РЕФОРМЫ ГОСУДАРСТВЕННОЙ СЛУЖБЫ ОТНОСИТЕЛЬНО БОЛЬШЕГО УЧАСТИЯ ГРАЖДАН В ИНВЕСТИЦИОННЫХ ПРОЦЕССАХ ДЛЯ ЕВРОПЕЙСКОЙ И ЕВРОАТЛАНТИЧЕСКОЙ ИНТЕГРАЦИИ УКРАИНЫ}

Целью статьи является анализ реализации реформы государственной службы относительно большего участия граждан в инвестиционных процессах для европейской и евроатлантической интеграции Украины. Методика. Исследованы различные формы участия граждан в процессах государственного управления, что позволяет сформировать хороший баланс преимуществ и недостатков в этом прочессе для внедрения евроинтеграционных реформ на основе методов теоретического обобщения, группировки и сравнения. Анализ преимуществ и недостатков содействию участию граждан в процессах государственного управления базируется на методологии системного анализа и синтеза. Результаты. Выявлено на основе анализа основных преимуществ и недостатков, преимуществ от участия граждан в процессах государственного управления значительно больше, чем недостатков для обеспечения лучшего качества услуг и уровня жизни граждан. Исследованы главные недостатки участия граждан в процессах государственного управления, что поможет решать проблемы участия граждан в процессах государственного управления в контексте евроинтеграции. Разработаны различные формы участия граждан в проиессах государственного управления для того, чтобы сформировать хороший баланс преимуществ и недостатков в этом процессе с изелью внедрения евроинтеграчионных реформ. Проанализированы созданные различные уровни участия граждан в процессах государственного управления, что способствует эффективному привлечению граждан к процессам государственного управления для реализации евроинтеграционных реформ. Выявлено, что поддержка прочессов сочиально-экономической реформы государственной службы по стратегии государственного управления поможет осуществить основные европейские административные реформы государственного управления в Украине. На основе анализа сделан вывод, что поддержка трансформаџионных процессов в Украине путем инвестирования в реформирование государственной службы помогает построить основные европейские принципы государственного управления в Украине. Научная новизна. Обоснована целесообразность создания различных уровней участия граждан в процессах государственного управления: информирование, консультирование, рекомендации, совместная разработка планов, общие решения, делегирование. Практическая значимость. Результаты исследования формируют научно-практическую основу для проведения вариативных аналитико-прогнозных исследований в части обоснования большего участия граждан в инвестиционных процессах государственного управления.

Ключевые слова: инвестирование, инвестиционный процесс, европейская и евроатлантическая интеграция, процессы государственного управления, реформа государственной службы, профессиональная подготовка государственных служащчих, участие граждан

Кулаков Алексей Алексеевич - доктор философии по экономическим наукам (к.э.н.), главный специалист отдела международного и межрегионального сотрудничества управления внешнеэкономических отношений,

Департамент инвестиционно-инновационного развития и внешних отношений

Донецкой областной государственной администрации,

E-mail: oleksiikulakov@ukr.net 